\title{
Physical and spectroscopic characterization of Pakistani honey
}

\author{
Saif-ur-Rehman, Zia Farooq Khan, and Tahir Maqbool \\ Department of Chemistry, Faculty of Science, The Islamia University of Bahawalpur 63100 Pakistan.
}

\begin{abstract}
Saif-ur-Rehman, Zia Farooq Khan, and Tahir Maqbool. 2008. Physical and spectroscopic characterization of Pakistani honey. Cien. Inv. Agr. 35(2):199-204. Honey is a naturally sweet and viscous fluid produced by honeybees (Apis mellifera) from the nectar of flowers that, by definition, does not include any other substances. The objectives of this work were to characterize Pakistani honey, physically and chemically in relation to international standards, and to study the effects of adulteration with sugar syrup on the physical properties of honey. For this purpose, 200 honey samples obtained from 15 different locations in Pakistan, ranging from desert to hilly areas, were collected in 2005-2006. Samples were prepared by the acid digestion method. Physical properties, conductance, surface tension, and $\mathrm{pH}$ were determined using digital instruments. The most abundant minerals found in Pakistani honey samples were $\mathrm{K}, \mathrm{Na}, \mathrm{Ca}, \mathrm{Mg}, \mathrm{Fe}, \mathrm{Zn}, \mathrm{Cu}, \mathrm{Ni}$ and $\mathrm{Co}$, with $\mathrm{K}$ accounting for almost $83 \%$ of the total mineral composition. Most Pakistani honey samples met international standards. However, some samples showed altered parameters, reflecting possible adulteration. A considerable change in viscosity was observed only in adulterated honey samples containing more than $50 \%$ of a saturated sugar solution.
\end{abstract}

Key words: Acid digestion, AAS, honey adulteration, honey, major and minor elements, physical properties.

\section{Introduction}

Honey is a sweet and viscous fluid produced by honeybees from the nectar of flowers. It is defined as a pure and natural product that does not include any other substances, such as water or sweeteners (Wikipedia, 2008). This definition has been widely accepted by the food regulations of most nations, including Pakistan. It is important to note that honey produced by insects other than honeybees has very different properties. Therefore, this article refers exclusively to the honey produced by honeybees (Apis mellifera). Interestingly, honey has been cited in the Quran, a Holy book for Muslims (Section 16 Verse 68-69), in reference to its medicinal properties.

Liquid honey does not spoil because of its high

Received: 29 October 2007. Accepted 20 May 2008.

${ }^{1}$ Corresponding author: saif21@gmail.com sugar concentration and low moisture content, which kills most bacteria by plasmolysis and impedes the development of airborne yeasts. The moisture content of natural raw honey varies from $14 \%$ to $18 \%$. As long as the moisture content remains below $18 \%$, virtually no microorganisms can successfully multiply in honey.

The physicochemical properties of Eucalyptus honey have been studied and include the presence of palynol, low sucrose, traces of trisaccharides and the following mean mineral and trace element contents $\left(\mathrm{mg} \cdot \mathrm{kg}^{-1}\right)$ : $\mathrm{Ca}$ (221.9), $\mathrm{Mg}$ (54.15), K (579.6), Na (351.4), $\mathrm{Fe}$ (8.3), Cu (0.2), Cr (0.5), and Pb (1.1) (Serra, 1989; Visser, et al., 1989). Recently, Fernández-Torres (2005) studied the mineral composition of Spanish honeys of different botanical origins and found eleven minerals $(\mathrm{Zn}, \mathrm{P}, \mathrm{B}, \mathrm{Mn}, \mathrm{Mg}, \mathrm{Cu}, \mathrm{Ca}$, $\mathrm{Ba}, \mathrm{Sr}, \mathrm{Na}$ and $\mathrm{K}$ ). Twelve additional mineral elements were identified in honey samples from Italy (Pisani et al., 2008). In Poland, Rostkowski and Omieljaniuk (1989) found an average of 
$0.369 \mathrm{mg} \cdot \mathrm{kg}^{-1}$ of lead in honey samples with values that ranged from 0.007 to $1.21 \mathrm{mg} \cdot \mathrm{kg}^{-1}$. Therefore, there is considerable variation in mineral composition among honey samples of different origins.

The ascorbic acid content of honey has been determined (Men et al., 1989), and the nitrogen and protein contents have also been determined using novel methods (Siegfried, 1989). Similarly, Lvanov (1989) developed a method to identify sugars in honey containing lower levels of reducing sugars and higher levels of sucrose than natural honey. Nevertheless, the optical density of a $10 \%$ solution is the most reliable index for the identification of sugar in honey samples. A spectrophotometric method has been proposed to determine the sucrose content in honey samples (Rostkowski and Omieljaniuk, 1989).

Sato (1993) reviewed the standards for commercial honey, including assays for sugars, pollen and hydroxymethylfurfural. The presence of ethanol and other alcohols can be determined by enzymatic analysis, as it has long been recognized that honey can spoil by spontaneous fermentation, producing ethanol, carbon dioxide, and volatile and nonvolatile organic acids.

An analytical survey of honey in the United States has been reported (USDA, 2003). In this survey, considerable effort was made to obtain honey samples from throughout the United States and to include samples produced from different floral types. These results are useful to beekeepers and honey packers and also to food technologists. In addition to providing tables of the composition of U.S. honeys, general conclusions on various factors that affect honey composition were presented in this study.

The study of the physical and chemical properties of honey has increased in recent years because these parameters are important for the certification process that determines honey quality. The objectives of this study were to characterize Pakistani honey with respect to international standards and to investigate the effects of adulteration with sugar syrup on the physical properties of honey.

\section{Materials and methods}

Sample collection and pre-treatment. Two hundred honey samples were collected from locations situated in deserts (D), plains (P), hilly areas $(\mathrm{H})$, and from commercially available honeys (C) in Pakistan (Table 1). All samples were stored in glass jars at room temperature $\left(25 \pm 2^{\circ} \mathrm{C}\right)$.

Physical analysis. To determine the effect of adulteration on the physical properties of honey, 10, 20, 30, 40, 50, 60, 70, 80, 90 and $100 \%$ Young's French Honey was prepared in a saturated sugar solution $\left(1 \mathrm{~kg} \cdot \mathrm{L}^{-1}\right.$ of commercial white sugar in distilled water, heated at $100^{\circ} \mathrm{C}$ for $60 \mathrm{~min}$ ) (adulterated honey samples). Young's French Honey was used as a reference sample for pure honey. The density, refractive index, $\mathrm{pH}$, conductance, surface tension and viscosity of pure and adulterated honey samples were determined by standard methods (AOAC, 2000).

Chemical analyses. Ash and moisture content were determined by standard analytical methods. The total acid value of each honey sample was determined by acid-base titration (AOAC, 2000). Ascorbic acid content was determined by an analytical method based on the photochemical generation of iodine within the reaction mixture (Men, 1989). The sucrose content was determined using a colorimetric method (Bacilek et al., 1989).

Acid digestion was used to prepare honey samples for chemical analysis. $\mathrm{Fe}, \mathrm{Cu}, \mathrm{Zn}$, $\mathrm{Pb}, \mathrm{Ni}$ and $\mathrm{Mn}$ levels were determined using atomic absorption spectrophotometry (Perkins Elmer Analyst 100, USA). Na, K and Li levels were determined using a flame photometer (Corning 410, UK), and $\mathrm{Ca}$ and $\mathrm{Mg}$ levels were determined using EDTA titration (James and Prichard, 1974).

\section{Results and discussion}

Today, various techniques are applied to determine the elemental composition and physiochemical properties of honey and other foods. Among other methods, spectrophotometry, total X-ray reflection, and 
Table 1. Characteristics and geographical origins of honey samples $(n=200)$ used in this study.

\begin{tabular}{|c|c|c|c|}
\hline \multicolumn{2}{|c|}{ Honey samples } & \multirow[t]{2}{*}{ Geographical origin } & \multirow[t]{2}{*}{ Comments } \\
\hline Code & no. & & \\
\hline $\mathrm{B} 1(\mathrm{C})^{1}$ & 10 & Islamic Markaz Sahad Bahawalpur & Commercial brand \\
\hline $\mathrm{S} 1(\mathrm{C})$ & 10 & Islamic Markaz Sahad Bahawalpur & Commercial brand \\
\hline $\mathrm{S} 2(\mathrm{C})$ & 10 & Islamic Markaz Sahad Bahawalpur & Commercial brand \\
\hline $\mathrm{S} 3(\mathrm{P})$ & 15 & Chak No. 121 Rahim Yar Khan & Raw honey \\
\hline $\mathrm{S} 4(\mathrm{P})$ & 20 & Dara Bahka Bahawalpur & Commercial brand \\
\hline S5(D) & 20 & Mir Pur Matahlo Sindh & Commercial brand \\
\hline S6(C) & 15 & Local Market Rahim Yar Khan & Commercial brand \\
\hline $\mathrm{S} 7(\mathrm{P}+\mathrm{D})$ & 15 & Chak No 105/F Chistain & Raw honey \\
\hline $\mathrm{S} 8(\mathrm{C}+\mathrm{P})$ & 15 & Honey Farm Lahore & Farm honey \\
\hline $\mathrm{S} 9(\mathrm{H})$ & 10 & Local Market Mangora & Commercial brand \\
\hline $\mathrm{S} 10(\mathrm{P})$ & 10 & Local Market Multan & Commercial brand \\
\hline S11(D) & 15 & Chak No. 46/P Rahim Yar Khan & Raw honey \\
\hline $\mathrm{S} 12(\mathrm{C})$ & 10 & Marhaba Honey Company Product & Commercial brand \\
\hline S13(C) & 10 & French Honey Company Product & French commercial brand \\
\hline S14(D) & 15 & 13 Solang Yazman Mandi & Raw honey \\
\hline
\end{tabular}

${ }^{1} \mathrm{C}=$ commercial samples, $\mathrm{H}=$ samples from hilly areas, $\mathrm{D}=$ samples from deserts, and $\mathrm{P}=$ samples from plains.

fluorescence spectrometry are commonly used. Based on our results, potentiometric titrations can be used to determine the acidity of honey samples. Using this titration method, we found that honey samples from Pakistan had $26 \pm 1.5$ milliequivalents of free acidity (Table 2). The $\mathrm{pH}$ of honey varied from $\mathrm{pH} 3$ to $\mathrm{pH} 5$; honey samples with a $\mathrm{pH}$ above 5 can be considered to be of low purity and low quality. Upon the addition of water, honey showed remarkable changes in all of its physical properties, with major changes occurring in conductance. Pure honey is characterized by a conductance near zero. In the Codex Alimentarius, the maximum electrical conductivity for pure floral honey is $0.8 \mathrm{Ms}^{\cdot} \mathrm{cm}^{-1}$ (Bogdanov et al., 2000). Our results indicate that if honey is adulterated with water or saturated sugar solutions, it will display greater conductance than pure honey.

The most abundant minerals found in Pakistani honey samples were $\mathrm{K}, \mathrm{Na}, \mathrm{Ca}, \mathrm{Mg}, \mathrm{Fe}, \mathrm{Zn}, \mathrm{Cu}$, $\mathrm{Ni}$ and $\mathrm{Co}$ (Table 3). Similar to previous results (Adebiyi et al., 2004), $\mathrm{K}$ accounted for almost $83 \%$ of the total mineral composition. This is due to the high levels of $\mathrm{K}$ in plant tissues. Nutritionally, the presence of these metals makes honey an excellent food for humans, especially for children. The honey samples we tested had different viscosity, refractive index and $\mathrm{pH}$ values, which can be attributed to the fact that the percentage of different elements in honey varies during the growing season and across geographical areas.

Table 2. Physical and chemical characterization of honey samples from Pakistan.

\begin{tabular}{lcc}
\hline Parameters & $\begin{array}{c}\text { Experimental } \\
\text { values }\end{array}$ & $\begin{array}{c}\text { Reference } \\
\text { values }^{1}\end{array}$ \\
\hline Surface tension, dynes $\cdot \mathrm{cm}^{-1}$ & $61.90 \pm 0.86$ & 66.30 \\
$\mathrm{pH}$ & $4.30 \pm 0.27$ & 4.40 \\
Conductance, Ms $\cdot \mathrm{cm}^{-1}$ & $0.05 \pm 0.01$ & 0.18 \\
Moisture, $\%$ & $16.60 \pm 2.49$ & 17.20 \\
Ash, $\mathrm{g}$ & $0.30 \pm 0.08$ & 0.32 \\
Refractive index, $\mathrm{n}$ & $1.47 \pm 0.01$ & 1.49 \\
Acid value, milliequivalents acid per $1000 \mathrm{~g}$ & $26.00 \pm 1.5$ & 29.00 \\
Density, $\mathrm{g} \cdot \mathrm{cm}^{-1}$ & $1.50 \pm 0.04$ & - \\
Sucrose, $\mathrm{g}$ & $1.52 \pm 0.33$ & - \\
\hline
\end{tabular}

${ }^{1}$ Adebiy et al., 2004. 
Table 3. Mineral composition of honey samples from Pakistan.

\begin{tabular}{|c|c|c|c|c|}
\hline \multirow[t]{2}{*}{ Minerals } & \multicolumn{4}{|c|}{ Mineral content, $\mathrm{mg} \cdot \mathrm{kg}^{-1}$} \\
\hline & Minimum & Maximum & Mean & Reference values \\
\hline $\mathrm{Ca}$ & 51.0 & 71.0 & $58.47 \pm 3.2$ & $47.7-341.0$ \\
\hline $\mathrm{Mg}$ & 18.0 & 39.0 & $35.43 \pm 0.2$ & $13.3-136$ \\
\hline $\mathrm{K}$ & 340.0 & 1480.0 & $891.3 \pm 14.5$ & $296-1935$ \\
\hline $\mathrm{Na}$ & 71.0 & 89.0 & $79.18 \pm 3.15$ & $11.8-279$ \\
\hline $\mathrm{Fe}$ & 4.35 & 7.54 & $5.744 \pm 0.42$ & $3.7-9.2$ \\
\hline $\mathrm{Zn}$ & 1.98 & 2.94 & $2.442 \pm 0.17$ & $1.3-7.8$ \\
\hline $\mathrm{Cu}$ & 1.46 & 1.94 & $1.753 \pm 0.10$ & $0.5-2.1$ \\
\hline $\mathrm{Co}$ & 0.84 & 1.12 & $0.9878 \pm 0.05$ & 2.3 \\
\hline $\mathrm{Ni}$ & 1.02 & 1.48 & $1.264 \pm 0.01$ & 0.7 \\
\hline
\end{tabular}

${ }^{1}$ References values were obtained from Pisani et al. (2008), Downey et al. (2005), Fernández-Torres et al. (2005), Conti (2000), and Latorre et al. (1999).

For most of the Pakistani honey samples tested, the $\mathrm{pH}$, conductance, viscosity, surface tension, refractive index, and moisture content fell within international standards. However, some of the samples showed altered parameters, possibly due to adulteration (Table 2). Similarly, the surface tension of honey depends on water content, and it increased with the addition of impurities. This could be due to a decrease in viscosity in adulterated samples. The $\mathrm{pH}$ of adulterated honey samples was higher than that of pure samples (Table 4).

The moisture content of pure honey should be between $14 \%$ and 18\%; although this number depends heavily upon the season and geographical conditions, for good quality honey, it should be in this range. Based on the results from raw and adulterated honey samples presented in Table 4, good quality honey must have a conductance between 0 to $0.02 \mathrm{Ms}^{\circ} \mathrm{cm}^{-1}$, a $\mathrm{pH}$ between 3.6 and 4.2, a surface tension between 58 and 65 dynes $\mathrm{cm}^{-1}$, and a refractive index between 1.45 and 1.47. Upon comparing the water content values shown in Table 2, it is clear that moisture content is low in honey samples obtained from plains or deserts compared to those from hilly areas. Honey with lower moisture content will have a longer shelf life.

Similar to previous studies (Fredes and Montenegro, 2006), the metals with the highest levels were $\mathrm{K}, \mathrm{Al}, \mathrm{Fe}, \mathrm{Mn}$, and $\mathrm{Zn}$ (Table 3). However, in Pakistani honey, $\mathrm{Al}$ was found in much lower amounts than in Chilean honeys (Fredes and Montenegro 2006). On the basis of our results and considering previously reported findings (Pisani et al., 2008), it is possible to conclude that the elemental composition of honey depends on soil composition, plant type, season, and environmental conditions. Also

Table 4. Characterization of pure non-adulterated raw honey and adulterated honey samples.

\begin{tabular}{lcc}
\hline Parameter & Raw samples & Adulterated $^{1}$ \\
\hline Surface tension, dynes $\cdot \mathrm{cm}^{-1}$ & $55.02 \pm 0.64$ & $68.0 \pm 1.03$ \\
$\mathrm{pH}$ & $4.2 \pm 0.3$ & $5.4 \pm 0.38$ \\
Conductance, $\mathrm{Ms} \cdot \mathrm{cm}^{-1}$ & $0.01 \pm 0.0001$ & $0.06 \pm 0.0001$ \\
Moisture, $\%$ & $16.7 \pm 1.32$ & $19.3 \pm 1.85$ \\
Ash, g & $0.38 \pm 0.04$ & $0.25 \pm 0.023$ \\
Refractive index, $\mathrm{n}$ & $1.472 \pm 0.001$ & $1.456 \pm 0.012$ \\
Acid value, miliequivalents acid per $1000 \mathrm{~g}$ & $30.0 \pm 1.0$ & $24.2 \pm 0.90$ \\
Density, $\mathrm{g} \cdot \mathrm{cm}^{-1}$ & $1.55 \pm 0.03$ & $1.62 \pm 0.03$ \\
\hline
\end{tabular}

${ }^{1}$ Pure, non adulterated honey samples and adulterated honey samples (including commercial brand samples) that were mixed with a saturated sugar solution. \pm , standard deviation. 


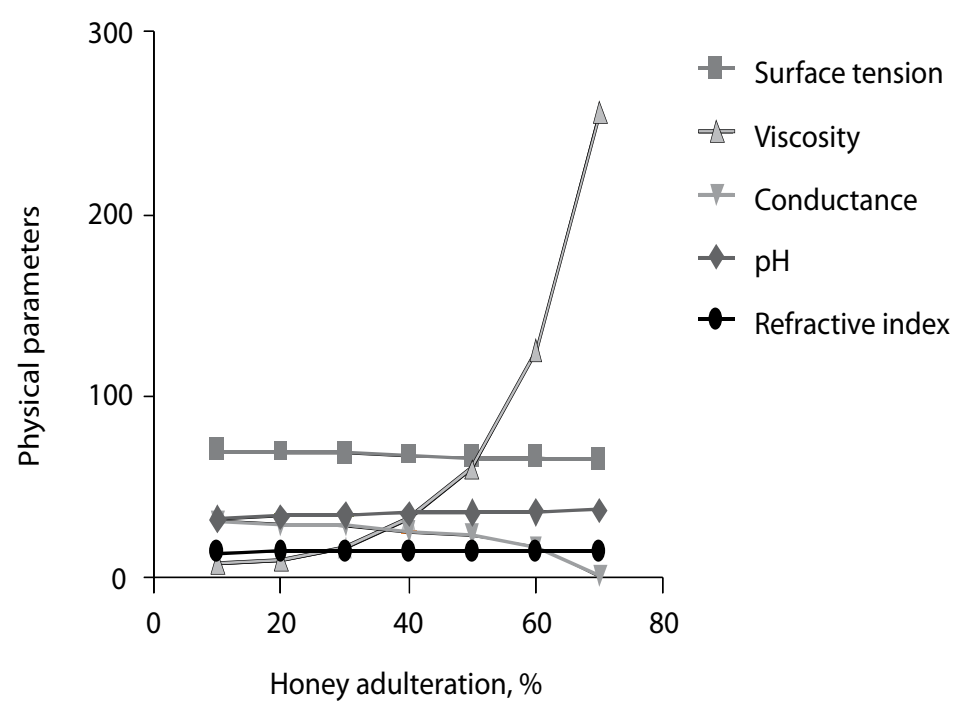

Figure 1. Effects adulteration on viscosity (MiliPoise) and other physical properties of honey. Honey samples were adulterated with a saturated sugar solution. Physical properties, such as surface tension (dynes $\mathrm{cm}^{-1}$ ), conductance $\left((\mathrm{Ms} \cdot \mathrm{cm} \cdot 1 \mathrm{x} 100)\right.$, refractive index $(\mathrm{x} 10)$, and $\mathrm{pH}(\mathrm{x} 10)$ remained almost constant. $\left(1 \mathrm{P}(\right.$ Poise $\left.)=1 \mathrm{~g} \cdot \mathrm{cm}-1 \cdot \mathrm{s}^{-1}\right)$.

based on the results obtained, the quality of most natural raw honey from Pakistan meets international standards.

\section{Acknowledgements}

The authors thank Umar Farooq, Department of Chemistry, The Islamia University of Bahawalpur, for help with metal analysis by AAS and data analysis.

\section{References}

Adebiyi, F.M., I. Akpan, E.I. Obiajunwa, and H.B. Olaniyi. 2004. Chemical/physical characterization of Nigerian honey. Pakistan Journal of Nutrition 3:278-281.

AOAC. 2000. Sugars and sugar products. In: Horwitz, W. (ed.). Official Methods of Analysis of AOAC International 2(44):22-33.

Bacilek, J., M. Marek, and J. Jary, 1989. Determination of sucrose in honey. J. Czech CS 3(87): 257-566.

Bogdanov, S., C. Lullmann, P. Martin, W.V.D. Ohe, H. Russmann, and G. Vorwohl. 2000. Honey quality, methods of analysis and international regulatory standards: Review of the work of the international honey commission, Swiss Bee Research Centre, FAM, Liebefeld, Switzerland.

Conti, M. E. 2000. Lazio region (central Italy) honeys: A survey of mineral content and typical quality parameters. Food Control 11:459-463.

Downey, G., K. Hussey, J.D. Jelly, T.F. Walshe, and P.G. Martin. 2005. Preliminary contribution to the characterization of artisanal honey produced on the island of Ireland by palynological and physicochemical data. Food Chemistry 91:347354.

Fredes, C., and G. Montenegro. 2006. Heavy metal and other trace elements contents in honey bee in Chile. Cien. Inv. Agr. 33:50-58.

Fernández-Torres, R., J.L. Pérez-Bernal, M.A. BelloLópez, M. Callejón-Mochón, J.C. JiménezSánchez, and A. Guiraúm-Pérez. 2005. Mineral content and botanical origin of Spanish honeys. Talanta 65:686-691.

James, M., and E. Prichard. 1974. Practical Physical Chemistry. Third ed., Longman Publishers, USA. 252 p.

Latorre, M.J., R. Peña, C. Pita, A. Botana, S. Garcia, and C. Herrero. 1999. Chemometric classification of honeys according to their type. II. Metal content data. Food Chemistry 66:263268. 
Lvanov, T.S. 1989. Experiments on bee keeping. Kubratovo, Bulg. Zhivotnovud. Nauki 25:96103.

Men, R., S. Liu, and S. Yan. 1989. Determination of ascorbic acid in food using photochemical generation of iodine. Fenxi Huaxue 17:903905.

Pisani, A., G. Protano, and F. Riccobono. 2008. Minor and trace elements in different honey types produced in Siena County (Italy). Food Chemistry 107:1553-1560.

Siegfried, R. 1989. Determination of protein and total nitrogen using FP-228 in comparison with other methods. Fresenius' Journal of Analytical Chemistry 335:489-492.

Rostkowski, J., and N. Omieljaniuk, 1989. Determination of lead content in honey in Poland, Bromatol. Chem Toksykol. 25:319-327.
Sato, S. 1993. Review on standards on honey. Gijutsu Joho-Shizuoka-Ken. Eisei Kankyo Senta 11:811.

Serra, B.J. 1989. A study of physicochemical properties of eucalyptus honey in Spain. An. Bromatol. 41:41.

Visser, R F., J.M. Allen, and G.J. Shaw. 1989. The effect of heat on the volatile flavour fraction from a unifloral honey. J. Apic. Res. 27:175-81.

USDA. 2003. Composition of American Honeys. United States National Honey Board, Technical Bulletin 1261. United States Department of Agriculture.

Wikipedia. 2008. http://en.wikipedia.org (Accessed: April 2008). 